\title{
Characteristics of the carcass and quality of meat of male and female calves with different high-grain diets in confinement
}

\author{
Características da carcaça e qualidade da carne de \\ novilhos e novilhas alimentados com diferentes dietas \\ de alto grão em confinamento
}

\author{
Jonatas Cattelam $^{1 *}$; Flânia Mônego Argenta²; Dari Celestino Alves Filho²; \\ Ivan Luiz Brondani²; Paulo Santana Pacheco ${ }^{2}$; Rangel Fernandes Pacheco ${ }^{3}$; \\ Andrei Retamoso Mayer"; Leonel da Silva Rodrigues ${ }^{5}$; \\ Patrícia Machado Martini ${ }^{6}$; John Lenon Klein ${ }^{6}$
}

\begin{abstract}
The goal of the present study was to evaluate characteristics of the carcass and meat of steers and heifers, finished in feed lots and fed different high-grain diets. Forty-five bovines were used: 21 heifers, with an initial age of 32 months and initial weight of $359.9 \mathrm{~kg}$, and 24 steers, with an initial age of 20 months and initial weight of $337.6 \mathrm{~kg}$, from a Charolais $\times$ Nelore crossbreed. The animals were divided among the treatments, which were defined by the energy source used in the diet: rice, white oats, or corn; seven heifers and eight steers were used per diet treatment. The animals remained confined until reaching an estimated warm carcass weight of $220 \mathrm{~kg}$. The experimental design was completely randomized, with a $3 \times 2$ factorial arrangement. Weights at slaughter were higher for animals fed white oats $(449.3 \mathrm{~kg})$ or corn $(430.4 \mathrm{~kg})$ than for animals fed rice $(401.8 \mathrm{~kg})$. Higher carcass yields were found in corn-fed animals. Animals that received rice had lower cover fat thickness. The yields of the rib and hind-quarter commercial cuts were higher for cattle that received white oats or corn. Animals that received corn diets had greater arm circumference than animals that received white oats and both were larger than animals that were fed rice. The tenderness ( 5.15 points) and palatability (5.46 points) of rice-fed animals were lower than those of animals fed white oats (5.73 and 6.40 points, respectively) or corn (6.04 and 6.45 points, respectively). Slaughter weights were similar between categories - 424.1 $\mathrm{kg}$ and $430.2 \mathrm{~kg}$ for steers and heifers, respectively. Steers had higher fore-quarter yield $(38.0 \% \mathrm{vs}$. $37.4 \%)$, whereas heifers had a greater carcass length $(126.0 \mathrm{~cm}$ vs. $123.1 \mathrm{~cm})$. The finishing of cattle with corn- or white oat-based high grain-diets yielded heavier carcasses, with adequate deposition of fat, and better performance of principal carcass cuts. Feeding with rice in high-grain diets produced leaner meats, but reduced carcass weight, with greater losses upon cooling and less tender meat. The production of confined heifers or steers ensures similar meat products.
\end{abstract}

Key words: Commercial cut. Corn. pH. Rice. Tenderness. White oat.

Prof. Dr., Universidade Federal da Fronteira Sul, UFFS, Realeza, PR, Brasil. E-mail: jonatas.cattelam@uffs.edu.br

2 Profs. Drs., Universidade Federal de Santa Maria, UFSM, Santa Maria, RS, Brasil. E-mail: flaniama@yahoo.com.br; darialvesfilho@hotmail.com; brondani@pq.cnpq.br; pacheco.dz.ufsm@hotmail.com

3 Prof. Dr., Instituto Federal de Farroupilha, IFFar, Frederico Westphalen, RS, Brasil. E-mail: rangelzootec@hotmail.com

${ }^{4}$ Prof. Dr., Instituto de Desenvolvimento Educacional do Alto Uruguai, IDEAU, Passo Fundo, RS, Brasil. E-mail: andreirm@bol. com.br

${ }^{5}$ Discente de Doutorado, Programa de Pós-Graduação em Zootecnia, UFSM, Santa Maria, RS, Brasil. Bolsista CAPES. E-mail: rodrigues_leonel@hotmail.com

${ }^{6}$ Discentes de Mestrado, Programa de Pós-Graduação em Zootecnia, UFSM, Santa Maria, RS, Brasil. Bolsista CAPES E-mail: patriciammartini@hotmail.com; johnlenonklein@yahoo.com

* Author for correspondence 


\section{Resumo}

O presente estudo teve por objetivo avaliar as características da carcaça e da carne de novilhos e novilhas, terminados em confinamento alimentados com diferentes dietas de alto grão. Utilizaramse 45 bovinos de duas categorias, sendo 21 novilhas com idade inicial de 32 meses e $359,9 \mathrm{~kg}$, e 24 novilhos com idade inicial de 20 meses e $337,6 \mathrm{~kg}$, oriundos do cruzamento entre as raças Charolês e Nelore. Os animais foram distribuídos nos tratamentos conforme a fonte energética utilizada na dieta, sendo essas: arroz; aveia branca ou milho, sendo utilizados sete novilhas e oito novilhos para cada dieta alimentar. Os animais permaneceram confinados até atingir, por estimativa, peso de carcaça quente de $220 \mathrm{~kg}$. O delineamento experimental foi o inteiramente casualizado, com arranjo fatorial 3 x 2 (três tratamentos e duas categorias). Os pesos ao abate foram superiores para os animais alimentados com aveia branca $(449,3 \mathrm{~kg})$ ou milho $(430,4 \mathrm{~kg})$ em relação aos animais que receberam arroz $(401,8$ $\mathrm{kg}$ ), com maiores rendimentos de carcaça para aqueles que receberam milho. Animais que receberam arroz apresentaram menor espessura de gordura de cobertura. Os rendimentos dos cortes comerciais costilhar e serrote foram superiores para os bovinos que receberam aveia branca ou milho. Para o perímetro de braço, animais que receberam milho foram superiores aos animais que receberam arroz, com comportamento intermediário para aqueles que receberam aveia branca. Animais que receberam arroz apresentaram maciez $(5,15$ pontos) e palatabilidade $(5,46$ pontos) inferiores em relação àqueles que foram alimentados com aveia branca (5,73 e 6,40 pontos, respectivamente) ou milho (6,04 e 6,45 pontos, respectivamente). Entre as categorias os pesos de abate foram similares, 424,1 kg e 430,2 kg para novilhos e novilhas, respectivamente. Os novilhos apresentaram maior rendimento de dianteiro (38,0 contra $37,4 \%)$ ao passo que novilhas demonstraram maior comprimento de carcaça (126,0 contra $123,1 \mathrm{~cm})$. A terminação de bovinos com dietas com alto grão a base de milho ou aveia branca produz carcaças mais pesadas, com adequada deposição de gordura e com melhor rendimento dos cortes principais da carcaça. A alimentação com arroz em dietas de alto grão produz carnes mais magras, porém reduz o peso de carcaça, com maior perda ao resfriamento e carne de menor maciez. A produção de novilhas ou novilhos confinados assegura produtos cárneos similares.

Palavras-chave: Arroz. Aveia branca. Cortes comerciais. Maciez. Milho. pH.

\section{Introduction}

Feeding feedlot-confined cattle is based on the use of silages plus concentrates, which, in addition to requiring technical equipment and machinery to produce, requires extensive areas that are subject to inclement weather and to greater employment and labor costs. Thus, the use of high-grain diets is a possible alternative to facilitate handling, because it precludes the need for silage. Recognizing this, alternatives should be sought to substitute roughage feeds for confined cattle, thus reducing operational costs and possible problems related to bad weather, as well as promoting intensification of the production chain for beef cattle (RESTLE et al., 2004).

Generally, corn is used as the main energy source in high-grain diets for finishing cattle, as this grain is produced all over Brazil and has good production indices. However, many other cereals are also produced in large quantities in national agriculture in Brazil. For example, Brazil is the world's largest producer of rice outside the Asian continent, and Rio Grande do Sul is the largest national producer; this state also is the largest producer of white oats (CONAB, 2014). Thus, these two crops can be important sources for high-energy feeds for cattle in situations where there is both good availability of these grains and corn prices are high.

Another relevant aspect regarding the intensification of beef cattle production is the reduction in calf-slaughtering age. Greater selective pressure directs culled heifers towards slaughtering to generate a quicker financial return and capital turnover on the property. According to Millen et al. (2009), males are the main category used for feedlot termination, however, females account for $47.6 \%$ of the total cattle slaughtered in Brazil (ANUALPEC, 
2014). According to Pacheco et al. (2013), even with the great importance of culled-cow slaughtering for meat production, and as income generators in rural properties, little scientific information is generated regarding some characteristics of the female carcass in Brazil. Cattelam et al. (2009) evaluated the characteristics of the carcass and beef of steers and culled cows and found a greater proportion of muscle in bull carcasses and of fat in heifer carcasses, but with similar organoleptic characteristics and meat shear forces between the different bovine categories. Thus, the objective of this study was to evaluate carcass characteristics and the quality of the meat of steers and heifers finished in feedlots, fed a highgrain diet.

\section{Materials and Methods}

All animal protocols used in this study were approved by the Committee of Ethics for the Use of Animals of the Federal University of Santa Maria (UFSM), protocol number 145/2014. The experiment was carried out between July-October at the Beef Cattle Laboratory (LBC) at the Department of Animal Science, Federal University of Santa Maria, located in the municipality of Santa Maria, Rio Grande do Sul, in the Central Depression physiographic region of the state of Rio Grande do Sul. The climate of the region is subtropical with hot and humid summers, according to the Köppen scale (ALVARES et al., 2013).

A total of 45 male and female cattle were used: 21 heifers with a mean initial age of 32 months and weight of $359.9 \mathrm{~kg}$, and 24 steers with a mean initial age of 20 months and weight of $337.6 \mathrm{~kg}$, of Charolais $\times$ Nelore crossbreeds $(65 \%$ Charolais $35 \%$ Nelore or $65 \%$ Nelore $35 \%$ Charolais). Prior to the experimental period, the animals were adapted to both the facilities and diets for 21 days. Over this period, endoparasite control was performed with subcutaneous application of an Albendazole-based product ( $1 \%$ concentration), following the dosage recommended by the manufacturer.

The animals were divided among treatments according to the energy source used in the diet: whole grains and husks of rice, white oats, or corn. Seven heifers and eight steers were used per treatment, with the animals individually maintained in paved, semi-covered boxes furnished with individual feeders and drinkers with water ad libitum, regulated with a float faucet, common to two boxes. During the experimental period, the animals received isonitrogenated rations, adhering to the formulation in Table 1, according to the respective treatment.

The animals were fed twice daily, at 08:00 AM and 02:00 PM. Before the first feeding of the day, the leftovers from the previous day were collected, which were pre-established to be between 50 and $80 \mathrm{~g} / \mathrm{kg}$ of the offered feed (CALLEGARO et al., 2015). The animals were weighed at the beginning of the experimental period and at intervals averaging 28 days until shipment to the refrigerator. Animals were fasted for solids and liquids for $14 \mathrm{~h}$ before weighing (CATTELAM et al., 2013). Slaughtering was carried out at two times - after 67 and 79 days of feedlot confinement and a balanced number of animals per category and treatment were sent for each slaughtering. The time of slaughter was predetermined when steers and heifers reached an estimated $220 \mathrm{~kg}$ of warm carcass weight (SILVA et al., 2003), as this weight value is accepted by the cold storage industry. Cattle were transported to the commercial slaughterhouse and the slaughter was carried out according to the Regulamento da Inspeção Industrial e Sanitária de Produtos de Origem Animal (RIISPOA,1952), following the standard procedures of the slaughter line of the slaughterhouse. 
Table 1. Percentage composition and bromatological analysis of diets.

\begin{tabular}{lccc}
\hline \multirow{2}{*}{ Ingredient } & \multicolumn{3}{c}{ High grain diet } \\
\cline { 2 - 4 } Corn & Rice & White Oats & Corn \\
White oats & - & - & 83.5 \\
Rice & - & 84.0 & - \\
Urea & 83.4 & - & - \\
Calcitic limestone & 0.9 & - & 0.5 \\
Commercial sector & 0.7 & 1.0 & 1.0 \\
& 15.0 & 15.0 & 15.0 \\
Dry matter & & Bromatological composition & \\
Raw protein & 89.14 & 90.62 & 89.77 \\
Ether extract & 14.20 & 14.97 & 14.17 \\
Neutral detergent fiber & 1.89 & 4.35 & 3.78 \\
Fiber in acidic detergent & 22.43 & 31.05 & 15.93 \\
Lignin & 17.76 & 15.25 & 5.28 \\
Silica & 5.79 & 3.77 & 1.36 \\
Ash & 2.21 & 0.63 & 0.40 \\
Total digestible nutrients & 9.92 & 7.64 & 5.20 \\
Total carbohydrates & 66.60 & 72.42 & 81.64 \\
Non-structural carbohydrates & 73.99 & 72.92 & 76.84 \\
Calcium (Ca) & 55.38 & 43.85 & 63.61 \\
Phosphorus (P) & 0.78 & 0.88 & 0.95 \\
\hline
\end{tabular}

During slaughter, all parts of the animal's body were separated and weighed individually and consisted of the following sets: external components, vital organs, internal fats, empty digestive tract, and blood. The empty body weight was obtained by summing the warm carcass weight, blood, and all component groups mentioned above. The weight of the contents of the gastrointestinal tract was obtained by the difference between the slaughter weight and the empty body weight.

After slaughter, carcasses were washed, identified, weighed, and taken to a cold room, where they remained for $24 \mathrm{~h}$; the cold chamber temperatures after $0,3,6,12$, and $24 \mathrm{~h}$ of cooling were $20,10,5.3,1$, and $0.5^{\circ} \mathrm{C}$, respectively. After cooling, carcasses were weighed once more to obtain the cold carcass weight. The yields of warm and cold carcasses were calculated in relation to slaughter weight, measured at the farm. The loss upon cooling was calculated by the difference between the warm and cold carcass weights, divided by the warm carcass weight. The values of $\mathrm{pH}$ and temperature were obtained using a digital $\mathrm{pH}$ meter and thermometer, with a penetrating electrode. Measurements of the Longissimus dorsi (steak) muscle, between the $10^{\text {th }}$ and $12^{\text {th }}$ ribs, were collected before carcass cooling $(0 \mathrm{~h})$ and after 3,6 , 12 , and $24 \mathrm{~h}$ of cooling.

After cooling the carcasses for $24 \mathrm{~h}$, the left-half carcass was separated into the three primary cuts: hind quarter (or rear), ribs (or needle point), and forequarter, according to the protocols described by Müller (1987). After being separated, the cuts were weighed to calculate their relative share to the 
cold carcass weight. In the cold right-half carcass, the following characteristics of the carcass were evaluated: carcass length, taken from the medial cranial border of the first rib and the anterior border of the pubic bone; leg length, corresponding to the distance between the anterior border of the pubic bone and the tibiotarsal joint; thickness of the thigh, measured between the lateral and medial surfaces of the upper portion of the thigh, using a compass; length of the arm, distance from the carpal radial articulation to the end of the olecranon; and perimeter of the arm, measured in its medial region. The compactness was calculated as the quotient between the cold carcass weight and the carcass length.

A horizontal cut between the $12^{\text {th }}$ and $13^{\text {th }}$ ribs was created to remove the portion called "HH", comprising the $10^{\text {th }}, 11^{\text {th }}$, and $12^{\text {th }}$ ribs according to the methodology described by Hankins and Howe (1946) adapted by Müller (1973) aiming to expose the Longissimus dorsi, to trace its contour in tracing paper, which was later determined, using a digital scanning table and the Corel Draw software, as the area of the figure. At the same site, subcutaneous fat thickness was measured as the average of three observations; subjective evaluations of marbling, color, and texture of the meat also were performed in a section of the Longissimus dorsi muscle at the height of the $12^{\text {th }}$ rib, according to the methodology described by Müller (1987). To determine tissue percentages, the methodology described by Hankins and Howe (1946) and adapted by Müller (1973) was followed.

The extracted portion of the Longissimus dorsi muscle was identified and frozen for further analysis of sensory characteristics. Two $2.5 \mathrm{~cm}$ thick strips were extracted from the still-frozen samples. Slice "A" was weighed while still frozen and after thawing to determine the loss of liquid during the thawing process and then was cooked to an internal temperature of $70^{\circ} \mathrm{C}$ to evaluate the loss of liquid during cooking. After this step, six, $1 \mathrm{~cm}^{3}$ fiberbundle samples, cut perpendicular to the muscle fibers, were used to evaluate the shear force using a Warner-Bratzler Shear apparatus. Slice "B", after a preparation similar to slice $\mathrm{A}$, was evaluated by a panel of six evaluators for tenderness, palatability, and succulence (MÜLLER, 1987).

The experimental design was completely randomized, in a $3 \times 2$ factorial arrangement (three treatments and two categories). All analyses were performed using the statistical package SAS (Statistical Analysis System, version 9.2). The data were analyzed using an analysis of variance (ANOVA) in proc GLM, using the following mathematical model:

$$
Y i j=\mu+K i+T j+(K i * T j)+\varepsilon i j
$$

where Yij represents the dependent variables; $\mu$ the overall mean of the observations; Ki the effect of the ith bovine category, $\mathrm{Tj}$ the effect of the $\mathrm{jth}$ food treatment; $\left(\mathrm{K}^{*} \mathrm{~T}\right) \mathrm{ij}$ the interaction between the ith category with the jth food treatment, and eij the random residual error. The means were compared using an $F$-test and the parameters for which there was a significant effect of food treatment and interactions between categories and food treatment were compared using a Student's $t$-test, at $\alpha=$ 0.05. The dependent variables were assessed for correlation using Pearson's correlation analysis (proc CORR). The variables were tested for normality using a Shapiro-Wilk test and transformations were performed when necessary.

\section{Results and Discussion}

There was no interaction between diets and categories for the variables of interest. Animals fed corn or white oats had higher slaughter weights than those fed a rice diet (Table 2), a fact that has been associated with the highest average daily gain of weight, as described by Argenta (2015). This result was reflected in the weights of warm and cold carcasses, with corn- and white oat-fed cattle having values $10.5 \%$ and $8.9 \%$ higher than animals fed rice, respectively. This result is highlighted as 
observed when slaughter weight was positively correlated with warm and cold carcass weights, with $\mathrm{r}=0.92(P<0.0001)$. The evaluation of carcass weight is a measure of interest of slaughterhouses in evaluating the value of the product and operational costs, as carcasses with different weights demand similar labor and times for processing. According to Pacheco et al. (2013), carcass weight is a very important characteristic for the producer, other than the degree of finishing and animal age, being directly related to income.

Mandarino et al. (2013) evaluated the productive characteristics of cattle fed diets that used $75 \%$ of concentrate or were based exclusively $(100 \%)$ on concentrate, and verified differences in warm carcass weights between the different food treatments - a fact these authors also associated with the difference in animal weight gain. Regarding yields of warm and cold carcasses, the highest yields were observed in corn-fed animals, followed by those maintained on a rice diet, and finally cattle fed white oats. The observed carcass-yield values followed the variations observed for gastrointestinal tract contents, with higher contents associated with lower-carcass yields. Moreover, a thicker fat cover over the carcass contributed to higher carcass yields of corn-fed animals, which resulted in lower losses upon cooling.

The animals fed white oats or corn had thicker fat covers on the carcass compared to animals that were fed rice (Table 2), which stems from the higher energy intake associated with these two diets. Although no difference was observed for NDT consumption (ARGENTA, 2015), the author acknowledged that for the laboratory evaluation, the samples were processed by grinding, thus exposing all the starch protected by the grain husks. Thus, for rice-fed animals, ruminal microorganisms are not able to degrade all starches present in the grains, due to the high silica and lignin content of the bark, which hinder enzymatic attack, reducing utilization of energy from the diet. When fat thickness was evaluated relative to $100 \mathrm{~kg}$ of cold carcass, the animals that received white oats exhibited a $30 \%$ higher deposition of adipose tissue than animals fed with rice; corn-fed animals had intermediate levels of adipose-tissue deposition.

Changes in subcutaneous fat deposition influenced carcass losses on cooling, which were higher in cattle receiving a rice- or white oat-diet and were lower in corn-fed animals. The greatest loss upon cooling for rice-fed animal carcasses was related to lower cover of fat deposited, given the protection that the adipose tissue confers against the loss of liquids. Menezes et al. (2014) observed that the increase in the fat-cover thickness of the carcass resulted in lower losses upon cooling. It should be emphasized that in this study, only cattle fed rice had subcutaneous fat thicknesses below $3 \mathrm{~mm}$, the minimum recommended value by the refrigeration industry, which, in addition to reducing losses upon cooling, also prevents the shortening of muscle fibers and the darkening of the external portion of the muscles covering the carcass (LAWRIE, 2005).

The area of the Longissimus dorsi, as assessed through multiple methods, was similar among the evaluated diets. This result demonstrates that, regardless of the grain used in our experimental cattle finishing, all three diets provided the animals with adequate nutrition to complete their muscle growth. Mendes et al. (2005) did not observe any difference for the Longissimus dorsi, as measured by either area $\left(\mathrm{cm}^{2}\right)$ or per $100 \mathrm{~kg}$ of cold carcass, in feedlot finishing steers fed a 45:55 ratio roughage: concentrate, with corn or corn partially substituted by soybean husk or maize germ meal used as an energy source. 
When carcass weights and yields were analyzed according to the sex of cattle, no difference was observed, which is probably associated with the similarity in slaughter weights. Likewise, Fernandes etal.(2008) evaluated the carcass traits ofbulls, steers, and cows from feedlot-finished Canchim cattle, and observed similarities in carcass yield. Other studies (MARCONDES et al., 2008; FERREIRA et al., 2009) also did not observe differences in carcass yields between male and female cattle finished in confinement. These results are interesting, from an economic perspective, because, generally, coldstorage industries remunerate producers differently for females, with a lower commercial value than males, stemming from the fact that female cattle have lower carcass yields. Thus, this premise is not always valid when the animals are finished in intensive production systems.

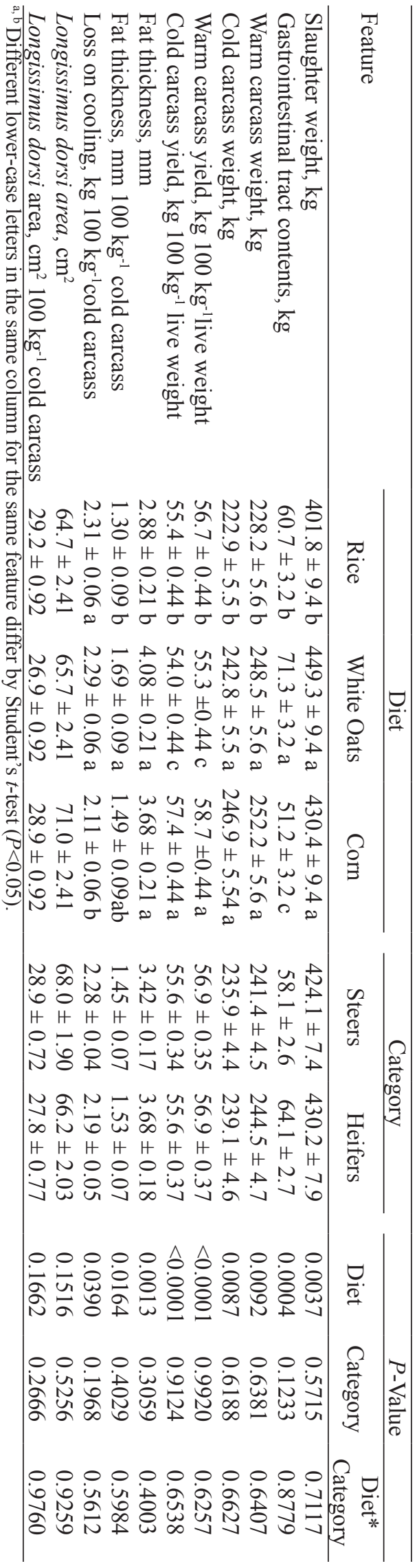

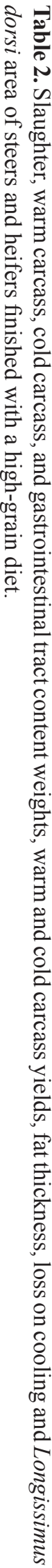


Thickness of subcutaneous fat did not differ between the evaluated categories, a fact that contributed to similarities in losses upon cooling. Greater deposition of fat could be expected for females, due to the more advanced stage of development of this subset, but the higher daily weight gain of steers $(1.13 \mathrm{~kg}$ vs. $0.91 \mathrm{~kg})$ contributed to the similarity in adipose tissue deposition. Similarly, Pazdiora et al. (2013) verified similarity in fat deposition and carcass yields in cows and heifers finished in feedlot. Pacheco et al. (2013) observed similarity in fat-cover deposition between steers and heifers finished in feedlot, with values of 3.8 and $3.6 \mathrm{~mm}$, respectively. For the Longissimus dorsi muscle area, the values observed in the present study are below those observed by Fernandes et al. (2008) for steers and cows, which were also similar to each other.

For the commercial rib cut (Table 3), animals fed white oats or corn had higher yields than animals on a rice diet, which should be associated with a higher fat thickness in the carcass of these animals. This idea is supported by the correlation between fat thickness and the rib cut yield $(\mathrm{r}=$ $0.35 ; P=0.0185)$. The yields of the fore-quarter and hind-quarter cuts were not influenced by the diet. Pazdiora et al. (2013) cited that the meat cuts of lower commercial value are in the fore quarter, mainly owing to tenderness, with most of these muscles directed to the production of ground meat. According to Pacheco et al. (2005), the hind-quarter cut is the most valued because it contains muscles with greater commercial value, generating more revenue for the refrigeration industry.

Among the categories of cattle studied, there was a difference only for the fore-quarter yield, with steers having a yield $1.60 \%$ higher than that of heifers, which stems from the greater muscular development in the anterior region of male bovines, owing to the performance of androgenic hormones during the growth phase. Greater yield of the fore quarter in male bovines compared to females was reported by Coutinho Filho et al. (2006), with average yields of $38.60 \%$ and $35.67 \%$, respectively. Likewise, Pascoal et al. (2009) observed higher forequarter yields in steers relative to culled cows, a fact that the authors attributed to the greater removal of fat shavings from female carcasses, however, fat did not differ between cattle of different categories in our study.

For the commercial rib cut, also known as needle-point, there was no difference between the categories of cattle evaluated. Ferreira et al. (2009) reported a higher development of this cut in females than in males, because of the increased arching promoted by gestation; the heifers in our study did not breed, a fact that resulted in similar values. Similarity in the rib-cut yield in male and female cattle with ages close to slaughter was reported by Marcondes et al. (2008). The rib cut is of greater regional interest, being much appreciated for the preparation of roasted meat in the cuisine from Rio Grande do Sul.

The performance of the hind-quarter cut was not altered by the animal category, which demonstrated the possibility of using male or female cattle to produce meat, without prejudice to the development of this cut. The mean yields observed for the different commercial cuts were close to those considered adequate by Luchiari Filho (2000), who states desirable carcass traits are $45-50 \%$ of hind quarter, $38-43 \%$ of front quarter with five ribs, and $12-16 \%$ of needle point.

Regarding the metric measurements of the carcass, there was a difference only for the perimeter of the arm, which was larger in corn-fed animals. Rice- and white oat-fed animals were similar to one another. All other carcass measurements were similar among the evaluated diets, which shows that the use of any of the tested grains does not alter bone growth in animals, likely because this is an early growth tissue. When evaluating different energy sources in the finishing of Nelore cattle, fed a 39:61 roughage:concentrate diet using corn meal, corn germ meal, soybean husk, or citrus pulp as energy 
sources, Ezequiel et al. (2006) did not observe alterations in the evaluated corporal measures, a fact that the authors attributed to the similar racial composition of the animals. The compactness of animals who fed on white oats or corn was superior to that of animals on a rice diet, a result related to the higher cold-carcass weights of those animals, associated with similar carcass lengths between the bovines of the different treatments. Miotto et al. (2012) observed that carcass compactness decreased with the fraction of corn in the concentrated fraction of the diet.

When measurements of the carcass were evaluated among cattle categories, there was a difference only in carcass lengths-a result that stems from the older age of heifers - a fact that led to greater longilineal growth of the animals, without altering height-growth patterns. Greater carcass lengths in cows relative to steers were reported by Pascoal et al. (2009), who observed values of $137.67 \mathrm{~cm}$ for culled cows and $128.60 \mathrm{~cm}$ for steers. Similarity in measurements performed in the anterior portion of the carcass of male or female bovines of different ages are reported by Ferreira et al. (2009).

Bovines supplied with white oats had a lower relative proportion of muscle in the carcass than the animals undergoing the other treatments; together with the animals that received corn, they showed a higher percentage of adipose tissue in the carcass (Table 3). These results implied a lower relation between muscle and adipose tissues for cattle that received white oats or corn, which shows a lower potential of lean meat production in the finishing system that employ diets based on these grains. According to Pacheco et al. (2005), studies on the relationship between these two tissues is rendered relevant by the worldwide importance given to current concerns about fat intake and its possible negative effects on human health, aggravated by sedentary lifestyles and lack of exercise. There is a consumer demand trend for lean meat; however, it is also necessary to produce carcasses with an adequate degree of finishing to avoid compromising the refrigeration industry. Tissue deposition comprises three stages: bone growth, muscle tissue, and finally, fat deposition, with the latter stage increasing in more advanced phases of animal development. Missio et al. (2013) point out that the proportion of muscles in the carcass tends to decrease in later stages due to the acceleration of adipose tissue development. Carcass compositions varyin the proportion of fat, whereas the percentages of muscle and bone decrease or remain constant with little variation.

When the composition of the tissues was analyzed according to the category of cattle studied, no difference was observed for any of the variables. Cattelam et al. (2009) reported higher fat deposition in the carcass of culled cows compared to steers, a result that the authors attributed to the females' more advanced stage of development. However, in the aforementioned study, females were 69 months old at slaughter. Thus, the difference of only one year among the bovine categories in this study was insufficient to promote alterations in tissue deposition in animal carcasses. Similar muscular and adipose tissue depositions in male and female cattle of similar ages were reported by Marcondes et al. (2008). Muscle is the most relevant tissue, as it is the one most desired by consumers; thus, the best carcasses for any market must have the highest proportion of muscle, minimal bone ratio, and an adequate amount of fat that varies according to consumer preference.

The $\mathrm{pH}$ values did not vary with diet over the different cooling times of the evaluated carcasses (Table 4), which probably stems from the good conditions of the cold room and adequate cattle management during the experimental period, as well as during the weighing, boarding into the refrigerator, and pre-slaughter handling. The values observed for $\mathrm{pH}$ at the time of entry of the carcasses in the cold chamber $(0 \mathrm{~h})$ are close to those reported by Cattelam et al. (2013). According to Kuber et al. (2004), the $\mathrm{pH}$ practically stabilizes after $6 \mathrm{~h}$ of cooling, with few variations until after $24 \mathrm{~h}$ 
post slaughter. However, in this study, the values were close to stabilization approximately $12 \mathrm{~h}$ after entering the cold chamber, as reported by Lopes et al. (2012), who reported that $\mathrm{pH}$ tends to stabilize 16-24 h post mortem. The $\mathrm{pH}$ values observed after $24 \mathrm{~h}$ of cooling were within the limits considered adequate - from 5.5-5.8 - and close to those reported by Sartor Neto et al. (2011) for feedlot Nelore cattle receiving $87 \%$ concentrate in the diet. The evaluation of the $\mathrm{pH}$ is of paramount importance for the determination of meat tenderness, because its decrease favors the release of proteolytic enzymes that improve tenderness, along with the acidification of the meat that increases its shelf life.

The temperature of the carcasses of animals that received rice was lower in the first measurement and after $3 \mathrm{~h}$ of carcass cooling. This decrease arose from the lower fat thickness of the carcass, which grants less protection against muscular cooling, with a correlation of fat thickness and the temperature of the loin after $3 \mathrm{~h}$ of cooling of $\mathrm{r}=0.39(P=0.0075)$. The temperature values observed after $24 \mathrm{~h}$ of carcass cooling were close to those reported by Cattelam et al. (2013) for bovines slaughtered in the same commercial refrigerator.

The different grains used in the animals' diets did not alter meat color (Table 5). This fact likely is associated with similarities in the $\mathrm{pH}$ values of the Longissimus dorsi after $24 \mathrm{~h}$ of cooling, with the correlation between these variables being $\mathrm{r}=-0.33$ $(P=0.0252)$. This result demonstrates that high $\mathrm{pH}$ values were associated with darker meat cuts, stemming mainly from pre-slaughter stress, when the animal exhausts its muscle glycogen reserves rapidly. Regarding the organoleptic characteristics of the meat, the animals that received rice had reduced meat succulence. The tenderness of the meat of these animals, evaluated by a panel of tasters, was inferior in relation to the meat coming from animals that received corn or white oats. The decrease in meat quality should be associated with lower fat deposition in the carcass, as the total fat had a negative correlation with losses on cooking ( $\mathrm{r}=-0.33, P=0.0297$ ), and this loss of liquid was inversely related to succulence $(\mathrm{r}=-0.32$, $P=0.0341$ ). According to Lawrie (2005), the main components of succulence include water released at the beginning of chewing and the fat, which has a stimulatory effect on salivation.

Besides the decrease in meat tenderness being closely related to lower succulence $(r=0.57$, $P<0.0001$ ), the better meat tenderness of corn or white oat-fed cattle is partly a reflection of the higher contribution of these diets. Silveira et al. (2009) verified that the increase in the energy level of the diet promoted an improvement in the quality of the meat of confined cattle. The lower temperature of the carcasses in the first hours of cooling also affected meat tenderness and the correlation of the meat temperature after $3 \mathrm{~h}$ of cooling with the tenderness evaluated by the panel of evaluators was $r=0.32$ $(P=0.0340)$. Pereira et al. (2009) reported that the Longissimus dorsi temperature of animals with greater fat cover decreased less. A rapid lowering of muscle temperature can cause the meat to harden. 


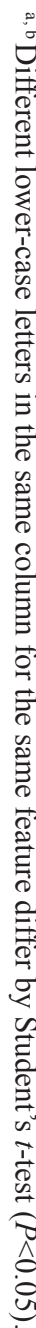

w un $\tilde{0}$

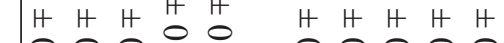
000.000000 u i d

$\stackrel{8}{\bar{E}}$ $w a-N \omega$ F

$\omega$ un $-\infty \omega$ $\infty$ 年 un

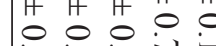
品克交式 苗

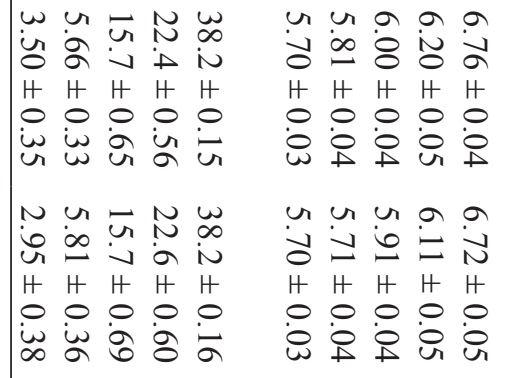
중.

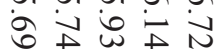
H H H H H 00000 인 융ㅇㅇ 00000 난ㅇㅇㅇ

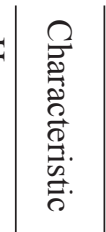

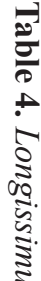

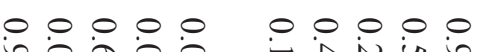

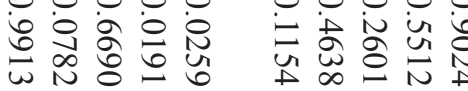

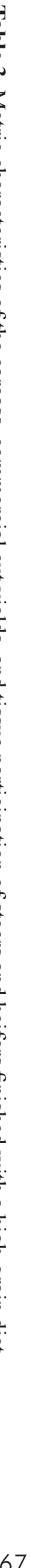


The softness of the meat evaluated by the Warner-Bratzler Shear apparatus did not differ between the tested diets, with a mean value of $7.64 \mathrm{kgF} \mathrm{cm}{ }^{3-1}$. Similarity in the shear forces of beef from cattle fed with different corn grains or sorghum in high-concentrate diets was reported by Igarasi et al. (2008). According to Shackelford et al. (1991), shear values above $9.0 \mathrm{~kg} \mathrm{~F} \mathrm{cm^{3 }}$ ${ }^{-1}$ characterize "hard meats", below $6.0 \mathrm{~kg} \mathrm{~F} \mathrm{~cm}^{3-1}$ "Tender meats", and between 6.0 and $9.0 \mathrm{~kg} \mathrm{~F} \mathrm{~cm}^{3-1}$ meats with "intermediate tenderness". Miotto et al. (2012) observed that the decrease in the contribution of corn as an energy source in the diet of confined cattle fed $80 \%$ concentrate increased the sheer force of the Longissimus dorsi muscle.

Meat characteristics did not differ among the different categories (Table 5), a fact that is related to similarity in tissue deposition in the carcass. This result demonstrates equal potential or steers and heifers to produce consumer-pleasing meat products. The color of the meat was classified as slightly dark red, similar to the values observed by Cattelam et al. (2009) for meat color of steers and culled cows. The color of the meat is affected mainly by the concentration of myoglobin, which is influenced by the age of the animal, among other factors. Thus, the difference of only one year of age between the categories was not enough to implicate a meat color alteration, in agreement with the results of Pacheco et al. (2005). The color of the meat is the first criterion of evaluation by the consumer at the time of purchase. Similarity in beef coloration of male and female cattle was reported by Fernandes et al. (2008). Regarding the organoleptic characteristics of the meat, the observed values classify the meat as slightly above average. Similarity in the sensorial characteristics of the meat of steers and heifers finished in feedlot was reported by Cattelam et al. (2009).

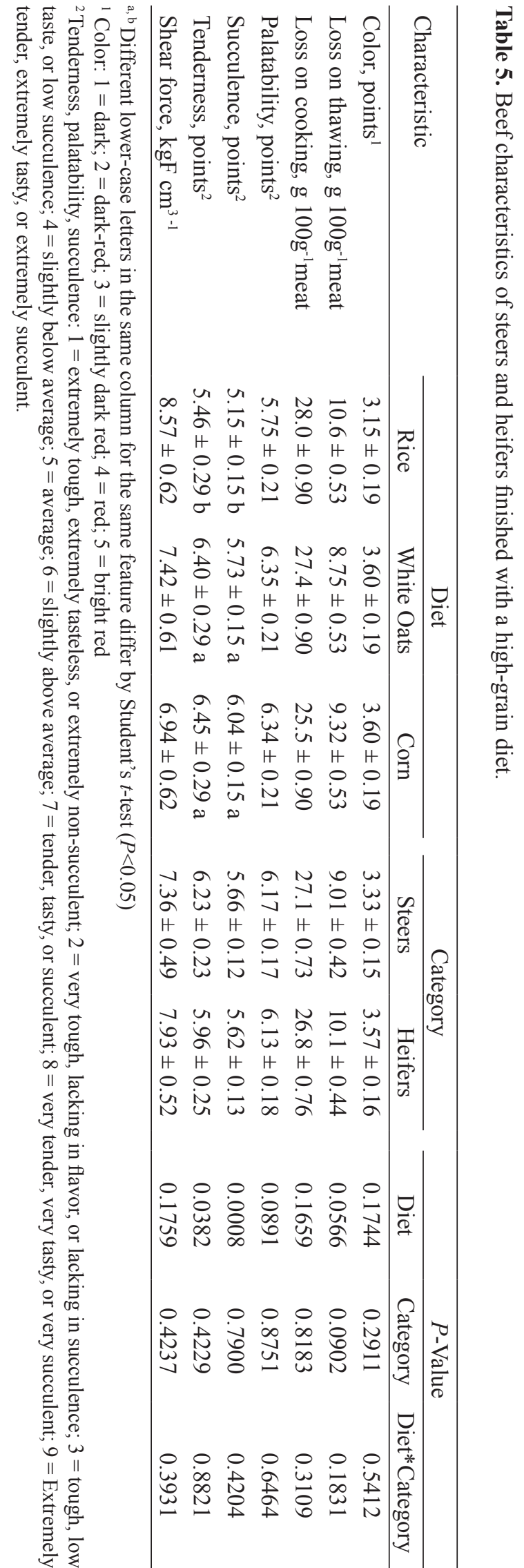




\section{Conclusions}

White oats can replace corn in high-grain diets at the finishing of cattle (with high-grain diets) without compromising either carcass or meat quality. Feeding with rice in high-grain diets produced leaner meats, but reduced carcass weight, with greater losses upon cooling and less tender meat.

The production of confined heifers or steers ensures similar meat products, with the choice of a category tied to the supply of animals and the specifications of the cold-storage industries for the acquisition of animals for slaughter.

\section{References}

ALVARES, C. A.; STAPE, J. L.; SENTELHAS, P. C.; GONÇALVES, J. L. M.; SPAROVEK, G. Köppen's climate classification map for Brazil. Meteorologische Zeitschrift, Stuttgart, v. 22, n. 6, p. 711-728, 2013.

ANUALPEC. Anuário da pecuária brasileira. São Paulo: Instituto FNP, 2014. 313 p.

ARGENTA, F. M. Grãos inteiros de milho, aveia branca ou arroz com casca na terminação de bovinos confinados - desempenho e comportamento ingestivo. 2015. Tese (Doutorado em Zootecnia) - Universidade Federal de Santa Maria, Santa Maria.

CALlegarO, A. M.; ALVES FILHO, D. C.; BRONDANI, I. L.; SILVEIRA, M. F.; PIZUTTI, L. A. D.; PAULA, P. C.; SILVA, V. S.; FREITAS, L. S.; SEGABINAZZI, L. R.; MACHADO, D. S.; MARTINI, A. P.; RODRIGUES, L. S. Consumo e desempenho de novilhos alimentados com borra de soja em confinamento. Semina: Ciências Agrárias, Londrina, v. 36. n. 3, p. 2055-2066, 2015. (Suplemento 1).

CATTELAM, J.; BRONDANI, I. L.; ALVES FILHO, D. C.; SEGABINAZZI, L. R.; CALLEGARO, A. M.; COCCO, J. M. Características de carcaça e qualidade da carne de novilhos confinados com diferentes espaços individuais. Ciência Animal Brasileira, Goiânia, v. 14, n. 2, p. 185-198, 2013.

CATTELAM, J.; MENEZES, L. F. G.; FERREIRA, J. J.; RESTLE, J.; BRONDANI, I. L.; ARBOITTE, M. Z.; PAULA, P. C. Composição física da carcaça e qualidade da carne de novilhos e vacas de descarte de diferentes grupos genéticos submetidos a diferentes frequências de alimentação. Ciência Animal Brasileira, Goiânia, v. 10, n. 2, p. 764-775, 2009.
COMPANHIA NACIONAL DE ABASTECIMENTO CONAB. Acompanhamento da safra brasileira: grãos. v. 1 Safra 2013/2014. Brasília: CONAB,2014. 127p. Disponível em: <http://www.conab.gov.br /OlalaCMS/ uploads/arquivos/14_09_10_14_35_09_boletim_graos setembro_2014.pdf>. Acesso em: 23 nov. 2014.

COUTINHO FILHO, J. L. V.; PERES, R. M.; JUSTO, C. L. Produção de carne de bovinos contemporâneos, machos e fêmeas, terminados em confinamento. Revista Brasileira de Zootecnia, Viçosa, MG, v. 35, n. 5, p. 20432049, 2006.

EZEQUIEL, J. M. B.; GALATI, R. L.; MENDES, A. R.; FATURI, C. Desempenho e características da carcaça de bovinos Nelore em confinamento alimentados com bagaço de cana-de-açucar e diferentes fontes energéticas. Revista Brasileira de Zootecnia, Viçosa, MG, v. 35, n. 5, p. 2050-2057, 2006.

HANKINS, O. G.; HOWE, P. E. Estimation of the composition of beef carcasses and cuts. Washington: USDA, 1946. 21p. (Technical Bulletin, USDA n. 926).

FERNANDES, A. R. M.; SAMPAIO, A. A. M.; HENRIQUE, H.; OLIVEIRA, E. A.; TULLIO, R. R.; PERECIN, D. Características da carcaça e da carne de bovinos sob diferentes dietas, em confinamento. Arquivo Brasileiro de Medicina Veterinária e Zootecnia, Belo Horizonte, v. 60, n. 1, p. 138-147, 2008.

FERREIRA, J. J.; MENEZES, L. F. G.; RESTLE, J.; BRONDANI, I. L.; ALVES FILHO, D. C.; CALllegaro, A. M. Características da carcaça de vacas de descarte e novilhos mestiços Charolês $\mathrm{x}$ Nelore em confinamento sob diferentes frequências de alimentação. Revista Brasileira de Zootecnia, Viçosa, MG, v. 38, n. 10, p. 1974-1982, 2009.

IGARASI, M. S.; ARRIGONI, M. B.; HADLICH, J. C.; SILVEIRA, A. C.; MARTINS, C. L.; OLIVEIRA, H. N. Características de carcaça e parâmetros de qualidade de carne de bovinos jovens alimentados com grãos úmidos de milho ou sorgo. Revista Brasileira de Zootecnia, Viçosa, MG, v. 37, n. 3, p. 520-528, 2008.

KUBER, P. S.; BUSBOOM, J. R.; DUCKETT, S. K.;MIR, P. S.; MIR, Z.; McCORMICK, R. J.; GASKINS, C. T.; CONRATH, J. D.; MARKS, J. D.; REEVES, J. J. Effects of biological type and dietary fat treatment on factors associated with tenderness: II. Measurements on beef semitendinosus muscle. Journal of Animal Science, Champaign, v. 82, n. 3, p. 779-784, 2004.

LAWRIE, R. A. Ciência da carne. 6. ed. Porto Alegre: Artmed, 2005. 384 p. 
LOPES, L. S.; LADEIRA, M. M.; MACHADO NETO, O. R.; PAUlinO, P. V. R.; CHIZZOTTI, M. L.; RAMOS, E. M.; OLIVEIRA, D. M. Características de carcaça e cortes comerciais de tourinhos Red Norte e Nelore terminados em confinamento. Revista Brasileira de Zootecnia, Viçosa, MG, v. 41, n. 4, p. 970-977, 2012.

LUCHIARI FILHO, A. Pecuária da carne bovina. São Paulo: Albino Luchiari Filho, 2000. 134p.

MANDARINO, R. A.; BARBOSA, F. A.; CABRAL FILHO, S. L. S.; LOBO, C. F.; SILVA, I. S.; OLIVEIRA, R. V.; DIOGO, J. M. S.; GUIMARÃES JÚNIOR, R. Desempenho produtivo e econômico do confinamento de bovinos zebuínos alimentados com três dietas de alto concentrado. Arquivo Brasileiro de Medicina Veterinária e Zootecnia, Belo Horizonte, MG, v. 65, n. 5, p. 1463 1471, 2013.

MARCONDES, M. I.; VALADARES FILHO, S. C.; PAUlino, P. V. R.; PAULINO, M. F.; DINIZ, L. L.; SANTOS, T. R. Consumo e desempenho de animais alimentados individualmente ou em grupo e características de carcaça de animais Nelore de três classes sexuais. Revista Brasileira de Zootecnia, Viçosa, MG, v. 37, n. 12, p. 2243-2250, 2008.

MENDES, A. R.; EZEQUIEL, J. M. B.; GALATI, R. L.; FEITOSA, J. V. Desempenho, parâmetros plasmáticos e características de carcaça de novilhos alimentados com farelo de girassol e diferentes fontes energéticas, em confinamento. Revista Brasileira de Zootecnia, Viçosa, MG, v. 34, n. 2, p. 697-702, 2005.

MENEZES, L. F. G.; SEGABINAZZI, L. R.; FREITAS, L. S.; RESTLE, J.; BRONDANI, I. L.; CALLEGARO, A. M.; JONER, G.; ALVES FILHO, D. C. Aspectos qualitativos da carcaça e carne de novilhos superjovens da raça Devon, terminados em pastagem tropical, recebendo diferentes níveis de concentrado. Semina: Ciências Agrárias, Londrina, v. 35, n. 3, p. 1557-1668, 2014.

MILLEN, D. D.; PACHECO, R. D. L.; ARRIGONI, M. D. B.; GALYEAN, M. L.; VASCONCELOS, J. T. A snapshot of management practices and nutritional recommendations used by feedlot nutritionists in Brazil. Journal of Animal Science, Champaign, v. 87, n. 10 p. 3427-3439, 2009.

MIOTTO, F. R. C.; RESTLE, J.; NEIVA, J. N. M.; RESENDE, P. L. P.; LAGE, M. E.; PRADO, C. S.; PADUA, J. T.; ARAUJO, V. L. Farelo de mesocarpo de babaçu (Orbygnia sp.) na terminação de bovinos: composição física da carcaça e qualidade da carne. Ciência Rural, Santa Maria, v. 42, n. 7, p. 1271-1277, 2012.
MISSIO, R. L.; RESTLE, J.;MOLETTA, J. L.; KUSS, F. NEIVA, J. N. M.; MOURA, I. C. F. Características da carcaça de vacas de descarte abatidas com diferentes pesos. Revista Ciência Agronômica, Fortaleza, v. 44, n. 3, p. 644-651, 2013.

MÜLLER, L. Normas para avaliação de carcaças e concurso de carcaça de novilhos. $2^{\text {th }}$ ed. Santa Maria: Universidade Federal de Santa Maria, 1987. 31 p.

Técnicas para determinar la composición de la canal. Memoria de La Asociación Latinoamericana de Producción Animal. Guadalajara: ALPA, 1973. 75 p.

PACHECO, P. S.; RESTLE, J.; MISSIO, R. L.; MENEZES, L. F. G.; ROSA, J. R. P.; KUSS, F.; ALVES FILHO, D. C.; NEIVA, J. N. M.; DONICHT, P. A. M. M. Características da carcaça de bovinos Charolês de diferentes categorias abatidos com similar grau de acabamento. Arquivo Brasileiro de Medicina Veterinária e Zootecnia, Belo Horizonte, v. 65, n. 1, p. 281-288, 2013.

PACHECO, P. S.; SILVA, J. H. S.; RESTLE, J.; ARBOITTE, M. Z.; BRONDANI, I. L.; ALVES FILHO, D. C.; FREITAS, A. K. Características quantitativas da carcaça de novilhos jovens e superjovens de diferentes grupos genéticos. Revista Brasileira de Zootecnia, Viçosa, MG, v. 34, n. 5, p. 1666-1677, 2005.

PASCOAL, L. L.; LOBATO, J. F. P.; RESTLE, J.; VAZ, R. Z.; VAZ, F. N. Meat yield of culled cow and steer carcasses. Revista Brasileira de Zootecnia, Viçosa, MG, v. 38, n. 11, p. 2230-2237, 2009.

PAZDIORA, R. D.; PAULA, P. C.; CALLEGARO, A. M.; METZ, P. A. M.; SILVEIRA, M. F.; MENEZES, L. F. G.; ARBOITTE, M. Z.; BRONDANI, I. L.; ALVES FILHO, D. C.; MOURA, A. F. Frequências do fornecimento da dieta sobre as características da carcaça bovina em confinamento. Archivos de Zootecnia, Cordoba, v. 62, n. 240, p. 567-577, 2013.

PEREIRA, P. M. R. C.; PINTO, M. F.; ABREU, U. G. P.; LARA, J. A. F. Características da carcaça e qualidade de carne de novilhos superprecoces de três grupos genéticos. Pesquisa Agropecuária Brasileira, Brasília, v. 44, n. 11, p. 1520-1527, 2009.

RESTLE, J.; FATURI, C.; ALVES FILHO, D. C.; BRONDANI, I. L.; SILVA, J. H. S.; KUSS, F.; SANTOS, C. V. M.; FERREIRA, J. J. Substituição do grão de sorgo por casca de soja na dieta de novilhos terminados em confinamento. Revista Brasileira de Zootecnia, Viçosa, MG, v. 33, n. 4, p. 1009-1015, 2004. 
RIISPOA. Regulamento da Inspeção Industrial e Sanitária de Produtos de Origem Animal. Decreto $\mathrm{n}^{\circ}$ 30691, de 29/03/52. Brasília: Ministério da Agricultura, Pecuária e Abastecimento, 1952. 212 p.

SARTOR NETO, A.; RIBEIRO, E. L. A.; MIZUBUTI, I. Y.; PEREIRA, E. S.; CUNHA, G. E.; SILVA, L. D. F.; BARBOSA, M. A. A. F.; BUMBIERIS JUNIOR, V. H. Desempenho e características da carcaça de bovinos Nelore confinados recebendo dietas de alto teor de concentrado com diferentes níveis de tanino. Semina: Ciências Agrárias, Londrina, v. 32, n. 3, p. 1179-1190, 2011.

SHACKELFORD, S. D.; MORGAN, J. B.; CROSS, H. R.; SAVELL, J. W. Identification of threshold levels for warner-bratzler shear force in beef top loin steaks. Journal of Muscle Foods, Trumbull, v. 2, n. 4, p. 289296, 1991.
SILVA, S. L.; LEME, P. R.; PUTRINO, S. M.; MARTELLO, L. S.; LIMA, C. G.; LANNA, D. P. D. Estimativa do peso e rendimento de carcaças de tourinhos Brangus e Nelore, por medidas de ultra-sonografia. Revista Brasileira de Zootecnia, Viçosa, MG, v. 32, n. 5, p. 1227-1235, 2003.

SILVEIRA, M. F.; BRONDANI, I. L; ARBOITTE, M. Z.; ALVES FILHO, D. C.; RESTLE, J.; PIZZUTI, L. A. D.; LUZ, T. R. R.;RETORE, M. Composição física da carcaça e qualidade da carne de novilhos Charolês e Nelore que receberam diferente proporções de concentrado na dieta. Arquivo Brasileiro de Medicina Veterinária e Zootecnia, Belo Horizonte, v. 61, n. 2, p. 467-474, 2009. 
